\title{
RHEUMATIC FEVER AS A COLLAGEN DISEASE*
}

\author{
BY \\ D. A. LONG \\ From the National Institute for Medical Research, London
}

(RECEIVED FOR PUBLICATION SEPTEMBER 23, 1954)

Rheumatic fever is typical of the collagen diseases in that lesions of mesenchyme, heart, blood vessels, joints, and serous membranes are frequently associated with hyperglobulinaemia, lymphadenopathy, and splenomegaly. Not only is the disease typical but it occurs more frequently and, being a prepubertal disease, is less complex than most of the diseases of the group. There are, therefore, several clues to its aetiology. These clues provide evidence by analogy as to the nature of collagen diseases in general.

Haemolytic Streptococci-Group A haemolytic streptococci are the most important factor in the pathogenesis of rheumatic fever. There is no simple bacteria-host relationship that can be defined in terms of Koch's postulates. It is the host, not the streptococcus, that decides the issue, for few patients with haemolytic streptococcal infection develop the disease. The syndrome occurs when recurrent attacks of haemolytic streptococcal tonsillitis have led to marked localization of the infection, a high level of antibodies, and frequently minimal constitutional disturbance until the development of rheumatic fever. The disease is part of what Rantz and others (1946) have termed "the post-streptococcal state". This state is always associated with hypersensitivity (of the tuberculin type) to streptococcal allergens; in the guinea-pig, at least, cells damaged by a specific streptococcal toxin are more susceptible to bacterial allergens than cells not so damaged, and this may in part explain the particular role of the streptococcus (Grey and Long, 1954). But the full rheumatic syndrome does not necessarily occur in all patients exhibiting sensitivity to streptococcal allergens.

\section{Nutritional Factors}

Essential Aminoacids.-It has been suggested that, of the many agents that influence susceptibility

* Read at the Third International Congress of Internal Medicine in Stockholm on September 16, 1954.
(Waksman, 1949), nutritional and hormonal factors $\vec{\omega}$ are the most important (Long, 1954), and that, in particular, a deficiency in essential sulphur contain $-\frac{0}{2}$ ing aminoacids is in part responsible for increased susceptibility to the disease. In support of this $\omega$ hypothesis is the fact that essential aminoacids $\vec{\omega}_{\omega}^{+}$ cannot be stored and therefore a deficiency is readily induced. Rheumatic fever is less common in theo protein-eating farming states than in the cotton and tobacco states of America (Peete, 1944). Egg consumption is lower in children who develop rheumatic fever than in those who do not (Wallis, 1954). $\frac{\mathbb{3}}{3}$ Powdered egg yolk prevented recurrence of rheumatic fever in underprivileged children in spite of ${ }_{-}$ recurrent attacks of haemolytic streptococcal infeg- $c$ tion (Coburn and Moore, 1943). It is noteworthy? that hyperglobulinaemia and multiple small areas cardiac necrosis have been described in conditionss attributed to a deficiency of animal protein (Davies, $\overline{0}$ 1952), and that of all sources of protein, egg protein

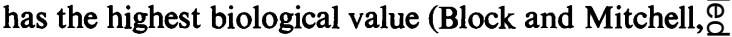
1946). Gamma globulin can be synthesized extra- $\overrightarrow{\vec{P}}$ hepatically even when a deficiency of essential 3 aminoacids has impaired hepatic synthesis of $\supset$ albumin. Whipple and others (1942) showed thatọ. although the body cannot store protein, there are large reserves in tissues which can be withdrawno without impairing vital function. Plasma proteins are readily replaced from tissues; conversely, plasma? proteins injected intravenously can supply all theo protein requirements of the body, suggesting that plasma protein can be readily incorporated into응 tissues. Neuberger and his colleagues (Harkness and $>$ others, 1954) have shown in the rat that protein electrophoretically indistinguishable from plasmañ protein is present, probably extra-cellularly, in large ? amounts in close association with the collagenous $N$ protein of connective tissue. It has been suggested $N_{\omega}^{N}$ that in the collagen diseases in general, and rheumatic fever in particular, connective tissue provideso protein and globulin for the general metabolic pool $\bar{\varnothing}$ (Long, 1954), this loss being associated with charac-? teristic degenerative changes in mesenchyme. 
Humphrey and McFarlane (1954) have recently shown that gamma globulin provides aminoacids for incorporation into liver cells. It is possible that under conditions of protein deficiency hyperglobulinaemia represents a compensatory phenomenon to increase the supply of aminoacids to the liver.

Ascorbic Acid.-Large amounts of ascorbic acid are needed to saturate and to maintain saturation in patients with rheumatic fever, with rheumatoid arthritis, and with active tuberculosis. It is possible that such patients oxidize ascorbic acid more readily than other patients and that this hypothesis might, through the intermediary glutathione, be linked with a deficiency of sulphur-containing aminoacids (Long, 1954).

\section{Hormonal Factors}

Of the various hormones, insulin and cortisone provide the most important clues.

Insulin.-Rheumatic fever seldom occurs in diabetics (Barach, 1926; Joslin, 1937); the development of diabetes in rheumatic patients reduces the incidence of heart damage (Joslin, 1937). Conversely, patients with rheumatic fever show "functional hyperinsulinism" (Steincrohn, 1938; Abrahamson, 1944). The symptoms of rheumatoid arthritis are relieved during the compensatory phase that succeeds insulin hypoglycaemia (Kersley and others, 1951). Two further facts are noteworthy: insulin and glutathione are closely related (Houssay, 1950), and the islets of Langerhans alone among the endocrine glands obtain their nerve supply from the parasympathetic.

Cortisone.-This relieves the symptoms of rheumatic fever and of many of the collagen diseases. The nerve supply of the adrenal cortex is from the sympathetic. Cortisone antagonizes many of the actions of insulin. It transfers aminoacids from carcase to liver, a phenomenon frequently associated with a reversion of hyperglobulinaemia to normal levels. It is possible that by this means cortisone makes good a deficiency in the liver of essential aminoacids and so removes the stimulus that induces hyperglobulinaemia. Again, the biological activity of cortisone is closely linked with the metabolism of glutathione (Long, 1954).

\section{Conclusions}

Rheumatic fever occurs in patients with marked hypersensitivity (of the tuberculin type) to streptococcal allergens. Eggs, and probably biologically valuable protein, decrease susceptibility to the disease. Hyperinsulinism increases, and hypoinsulinism decreases, susceptibility. Cortisone decreases susceptibility. Ascorbic acid requirements are increased. The common factor relating hypersensitivity to these nutritional and hormonal agents is the metabolism of sulphur-containing aminoacids and of glutathione.

These ideas have been criticized for being too complex. "The best hypotheses are the simplest. All current theories about the aetiology of rheumatic fever are complicated, and none more so than that recently suggested by Long" (Annotation, 1954). Of course, of any two hypotheses, either of which will

TABLE

ANALOGY BETWEEN RHEUMATIC FEVER IN MAN AND THE B.C.G.-INFECTED GUINEA-PIG*

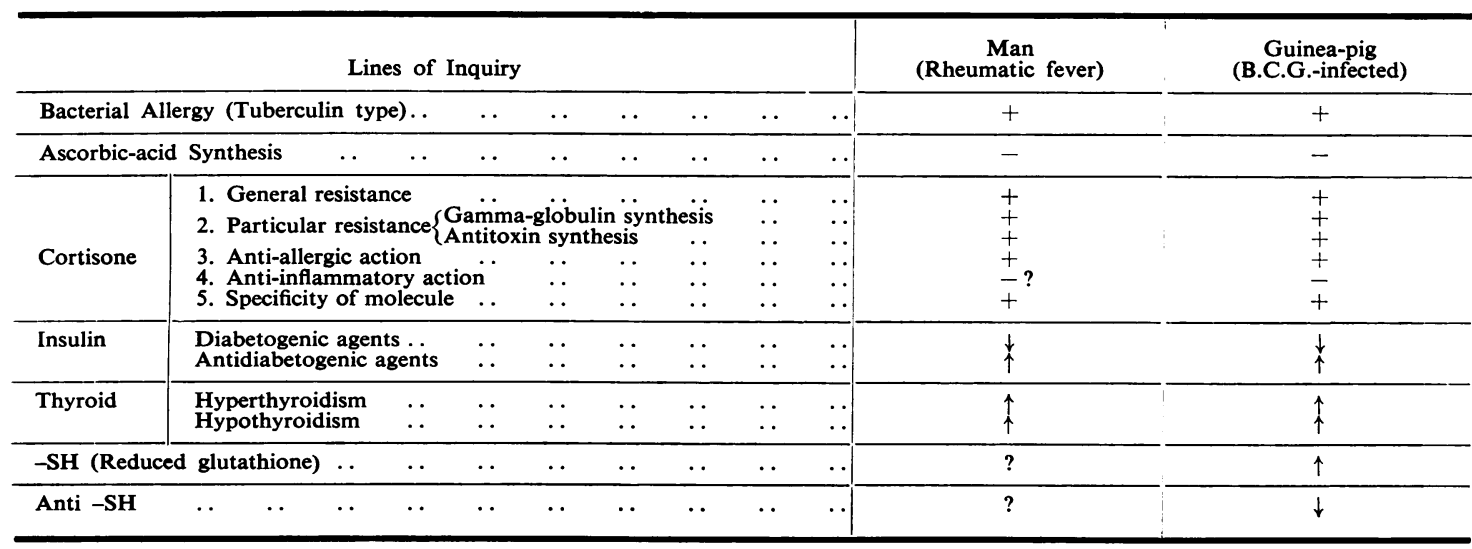


explain all the facts, the simpler is to be preferred. But what simple hypothesis will unite bacterial, allergic, nutritional, and hormonal hypotheses, or explain the analogy between the tuberculin sensitive guinea-pig and rheumatic fever? (Table). By considering a single facet of the problem and ignoring the rest, a simple hypothesis can be produced, but this is at the cost of seeking simplicity where none exists.

Rheumatic fever, though complex, is the collagen disease of which we know most; I have selected clues which can be followed and which may lead to a fuller understanding of the group as a whole.

\section{REFERENCES}

Abrahamson, E. M. (1944). J. clin. Endocr., 4, 71.

Annotation (1954). Brit. med. J., 1, 924.

Annot J. H (1926). Amer. Heart J 2, 196.

Block, R. J., and Mitchell, H. H. (1946). Nutrition Abstr. Rev., Block, R. J., and 249. Coburn, A. F., and Moore, L. V. (1943). Amer. J. Dis. Child.,

Davies, J. N. A. (1952). Ann. Rev. Med., 3, 99.

Grey, R. C., and Long, D. A. (1954). Brit. J. exp. Path., 35, 85.

Harkness, R. D. Marko, A. M., Muir, Helen M., and Neuberger, A. (1954). Biochem. J., 56, 558.

Houssay, B. A. (1950). Amer, J med. Sci., 219, 353

Humphrey, J. H., and McFarlane, A. S. (1954). Biochem. J., $57,195$.

Joslin, E. P. (1937). "The Treatment of Diabetes Mellitus", 6th ed. Lea and Febiger, Philadelphia.

Kersley, G. D., Mandel, L., Jeffrey, M. R., Bene, E., and Taylor, K. B. (1951). Brit. med. J., 2, 574.

Long, D. A (1954). Lancet, 1, 529.

Long, D. A. (1954). Lancet, 1, 529.

Steincrohn, P. J. (1938). J. Amer. med. Ass., 111,

Rantz, L. A., Spink, W. W., and Boisvert, P. J. (1946). Arch. intern. Med., 77, 66

Waksman, B. H. (1949). Medicine, Baltimore, 28, 143.

Wallis, A. D. (1954). Amer. J. med. Sci., 227, 167

Whipple, G. H. (1942). Proc. Inst. Med. Chicago, 14, 2.
Rhumatisme articulaire aigu comme maladie collagène RÉSUMÉ

Le rhumatisme articulaire aigu survient chez des $\square$ personnes douées d'une hypersensibilité marquée (type? de tuberculine) aux allergènes streptococciques. Des $\Rightarrow$ oeufs et probablement des protéines biologiquementô utiles réduisent la susceptibilité à cette maladie. Deo même l'hypoinsulinisme la réduit tandis que l'hyperinsulinisme l'accentue. La cortisone réduit la sus- $\frac{\bar{\sigma}}{\sqrt{0}}$ ceptibilité. La demande d'acide ascorbique se trouve $\frac{\mathcal{P}}{-}$ augmentée. Comme facteur commun entre l'hyper- $\mathbb{Q}$ sensibilité et les agents nutritifs et hormonaux men-o tionnés on trouve le métabolisme des aminoacides ${ }^{\text {s }}$ contenant du soufre et celui du glutathione.

Le rhumatisme articulaire aigu, bien que complexe, est une des maladies collagènes que nous connaissons $\vec{\omega}$ mieux; j'ai indiqué les pistes à suivre pouvant menero au meilleur entendement de l'entier groupe morbide.

Reumatismo poliarticular agudo como enfermedad colagena. Sumario

El reumatismo poliarticular agudo ocurre en personas con hipersensibilidad marcada (tipo de tuberculina) a loso alérgenos estreptocóccicos. Huevos y probablemente proteinas biológicamente útiles reducen la suscep- tibilidad a esta enfermedad. Asimismo el hipoinsulinismo la reduce mientras que el hiperinsulinismo la aumenta. La cortisona reduce la susceptibilidad. La 3 demanda de ácido ascórbico se ve aumentada. Comoo factor común entre la hipersensibilidad y los agentes ${ }^{\mathbb{D}}$ nutritivos y hormonales mencionados encuéntrase $\mathrm{el}-\overrightarrow{-}$ metabolismo de los aminoácidos que contienen azufrêôc la glutatión.

El reumatismo poliarticular agudo, aunque comple es la enfermedad colagena que conocemos mejor; 耳eo indicado aquí pistas que pueden llevar a la mejor comprensión del grupo mórbido entero. 